\title{
Halichondrin B
}

National Cancer Institute

\section{Source}

National Cancer Institute. Halichondrin B. NCI Thesaurus. Code C1376.

A complex macrolide polyether from marine sponge genera, such as Halichondria,

Axinella, Phakellia, and Lissodendoryx that binds to tubulin, thereby inhibiting mitosis.

$(\mathrm{NCl})$ 